\title{
Green Entrepreneurial Orientation and Green Innovation in Small and Medium-Sized Enterprises (SMEs)
}

\author{
Chaiyawit Muangmee ${ }^{1}$, Zdzisława Dacko-Pikiewicz ${ }^{2} \mathbb{D}$, Nusanee Meekaewkunchorn ${ }^{1}$ (D), Nuttapon Kassakorn ${ }^{1}$ \\ and Bilal Khalid ${ }^{3, *(D)}$ \\ 1 Faculty of Management Sciences, Bansomdejchaopraya Rajabhat University, Bangkok 10600, Thailand; \\ chaiyawit.m@bsru.ac.th (C.M.); nusanee.me@bsru.ac.th (N.M.); n.kassakorn@gmail.com (N.K.) \\ 2 Faculty of Applied Science, WSB University, 41-300 Dabrowa Górrnicza, Poland; zdacko@wsb.edu.pl \\ 3 KMITL Business School, King Mongkut's Institute of Technology Ladkrabang, Bangkok 10520, Thailand \\ * Correspondence: khalidb9998@gmail.com
}

check for updates

Citation: Muangmee, Chaiyawit, Zdzisława Dacko-Pikiewicz, Nusanee Meekaewkunchorn, Nuttapon Kassakorn, and Bilal Khalid. 2021. Green Entrepreneurial Orientation and Green Innovation in Small and Medium-Sized Enterprises (SMEs). Social Sciences 10: 136. https:// doi.org/10.3390/socsci10040136

Academic Editors: Beata Ślusarczyk, Aneta Pachura and Hana Štverková

Received: 16 March 2021

Accepted: 9 April 2021

Published: 13 April 2021

Publisher's Note: MDPI stays neutral with regard to jurisdictional claims in published maps and institutional affiliations.

Copyright: (c) 2021 by the authors. Licensee MDPI, Basel, Switzerland. This article is an open access article distributed under the terms and conditions of the Creative Commons Attribution (CC BY) license (https:// creativecommons.org/licenses/by/ $4.0 /)$.

\begin{abstract}
Since environmental issues are becoming an integral part of business performances, policymakers and managers have started recognizing the importance of green innovation towards sustainable business performances. The role of the automotive parts industry is crucial in minimizing environmental degradation and promoting sustainable development. Yet few studies have focused on the connection between green entrepreneurial orientation and green innovation that may affect small and medium enterprise (SME) business performance. Therefore, this study aims to analyze the influence of green entrepreneurial orientation on green innovations, and its effects on sustainable business performances in the automotive parts industry in Thailand. The sample consists of 226 SMEs in the automotive parts industry in Thailand. The partial least square method (PLS-SEM) has been used for the analysis of data. The results of the study show that green innovations have the strongest influence on economic and environmental performances. This study contributes to resource-based view theory by incorporating green innovation as a strategic competency of SMEs' performance. Further, green entrepreneurial orientation and green innovation can assist SME managers in understanding the factors leading to sustainable performance of businesses.
\end{abstract}

Keywords: green entrepreneurial orientation; green innovation; economic performance; environmental performance; social performance

\section{Introduction}

Increasing environmental issues are posing serious threats to humans, their economic growth, and ecology (Leonidou et al. 2017). Due to the heightened wave of environmental issues, governments and businesses are focusing on more sustainable productions and integrating sustainable processes in core business activities (Das and Rangarajan 2020; Liu et al. 2016). In particular, studies suggest that green entrepreneurial orientation (GEO) has a crucial role in realizing the environmental, economic, and social performance of organizations (Asadi et al. 2020; Jiang et al. 2018; Schaefer et al. 2015). Over the years, the views of scholars are split regarding the composition of green entrepreneurial orientation. For example, Lumpkin and Dess (1996) clearly state that entrepreneurial orientation is the combination of enterprise initiative and competitive aggressiveness that enables new behavior. Inferring from Arruda (1999), green entrepreneurial orientation is the combination of initiative and environmental orientation. Past studies indicate that social orientation and environmental orientation are two essential components of green entrepreneurial orientation (Cohen and Winn 2007). Studies on green entrepreneurial orientation reveal the significance of green entrepreneurial orientation due to the dynamic nature of the decision-making model (Jiang et al. 2018). The work of past scholars shows that green entrepreneurial orientation is embedded in a firm's proactive stance that enhances its 
capabilities to initiate green ventures and improve business performances (Jiang et al. 2018; Belás et al. 2014).

Green entrepreneurial firms have multiple mechanisms that may help them to contribute to superior environmental performances (Guo et al. 2020; Das and Rangarajan 2020). First, green entrepreneurial orientation designs new products and services that help to address environmental issues (Chang and Chen 2013). Second, it will improve employees' health and safety through reduced emission of toxic materials and carbon dioxide in the workplace (X. Xie et al. 2016; Y. Xie et al. 2016). Third, it will contribute to the social welfare of the consumers through health benefits and safety measures (Chuang and Yang 2014). Similarly, green entrepreneurial orientation enhances firms' financial performance in three different ways. First, it will address the issue of resource costs through product innovation processes (Chuang and Yang 2014). Second, in the pursuit of green opportunities firms will get the benefits of first mover in the industry (Pacheco et al. 2010). Third, firms get unusual profits from the investment of huge amounts on green projects (Woldesenbet et al. 2012). As a whole, green entrepreneurial orientation has a vital role in the improvement of an organization's social, economic, and environmental performance (Asadi et al. 2020; Jiang et al. 2018).

Small and medium enterprises (SME's) have a huge contribution to the gross domestic product (GDP) of Thailand, particularly the automotive parts industry of Thailand (Na-Nan et al. 2020). It is expected to become the global hub of green innovative industry (Suraraksa and Shin 2019). Due to expansion of the automotive industry, the suppliers of auto parts are increasing in the market (Rastogi 2018). As per estimates of Suraraksa and Shin (2019), local manufacturers have over $80 \%$ of the share in auto parts production. Therefore, it is essential to understand the importance of factors affecting the performance of the auto parts industry in Thailand. In line with this, the present study has developed a framework to understand the role of entrepreneurial orientation driving green innovation and performance of the auto parts industry in Thailand. The role of GEO in the development of emerging economies has been well studied by previous scholars (Jiang et al. 2018; Zhang et al. 2016; Zhao et al. 2009). However, the existing literature is limited on GEO, green product innovations, and sustainable business performances. Therefore, scholars have highlighted the need for research on the potential influence of SME's GEO on green innovations and several dimensions of sustainable business performances (Asadi et al. 2020; Na-Nan et al. 2020; Belas et al. 2019). The concept of green innovation was first proposed by Fussler and James (1996), which refers to improvements and innovations in product processes that enhance the environmental performance of the firms. In addition to this, Borghesi et al. (2015) refer to green innovation as the processes and use of innovative resources that may reduce the cost of production and improve organizations' performance. Past studies depict the importance of green innovations on firms' economic, environmental, and social performances, and enhancing the edge of the organizations (Asadi et al. 2020; Tamayo-Orbegozo et al. 2017).

This study has two important contributions to the literature on green entrepreneurship. First, the distinguishing point is the relationship between green entrepreneurial orientation and green innovation. Prior studies in this area have considered the influence of green entrepreneurial orientation on sustainable business performances (Jiang et al. 2018; Galbreath 2019). Another distinctive contribution of this study is the relationship between green innovation and sustainable business performances. Although researchers have studied the effect of green innovation on economic and environmental performances, yet social performance is still unclear for the managers. Furthermore, this study enriches the body of literature in the context of the automotive industry in Thailand. These potential gaps in the literature provide valuable space for understanding the importance of green entrepreneurial orientation on green innovation and firm performance in the context of the automotive industry in Thailand. Therefore, the current study will put emphasis on the influence of green entrepreneurial orientation on green innovation and SMEs' performance in the automotive industry of Thailand. The outcomes of this study will provide useful in- 
sights to SMEs' managers that help them to compete in the dynamic business environment and achieve sustainable business performance.

\section{Literature Review}

\subsection{Theoretical Foundation: Resource-Based View Theory}

This study is based on the principles of the resource-based view (RBV) to examine the influence of green entrepreneurial orientation on green innovation of small and medium enterprises (SMEs) in the automotive parts industry in Thailand. Further, this study focuses on the influence of green innovations on SMEs' social, economic, and environmental performance. The resource-based view theory was first proposed by Wernerfelt (1984) and explains that organizations' unique capabilities create a competitive advantage in the market. From the perspective of RBV, organizations' rare and inimitable characteristics help to achieve a sustainable competitive edge (Jiang et al. 2018; Sirmon et al. 2010; Varanavicius and Navikaite 2015). Further, Xie et al. (2019) inferred that organizational unique internal and external resources are crucial factors that create competitive advantage. Due to excessive internal and external pressure to comply with environmental regulations, firms are comprehensively implementing green strategies (Asadi et al. 2020; Weng et al. 2015). Green strategies require firms to adopt green technologies, design green products, and implement green supply chain practices in the organization (Rosenbusch et al. 2011; Chiou et al. 2011). From the resource-based view (RBV) theory, green entrepreneurial orientation leads to green innovation that creates a competitive edge and affects the environmental, social, and economic performance of the businesses.

\subsection{The Relationship between Green Entrepereneurial Orientation and Green Innovation}

The green entrepreneurial orientation (GEO) concept is based on the foundation of green entrepreneurial theory and entrepreneurship orientation theory (Guo et al. 2020). GEO follows the principle of a triple bottom line that is aimed at the development of enterprises. The work of Luo et al. (2005) indicated the importance of availing green innovation through proper allocation of resources that reduce the hazardous impact on the environment. Specifically, some scholars asserted that green entrepreneurial orientation includes two aspects: environmental orientation and social orientation (Guo et al. 2020; Cohen and Winn 2007). Furthermore, Becker (2010) argued that GEO is comprised of social and innovative orientation. Notably, as a strategic move, green entrepreneurial orientation (GEO) may facilitate the production of green innovative products that will help to enhance sustainable business performances (Guo et al. 2020; Teece 2016). As such, the main goal of GEO is to promote sustainable production processes and introduce green products and services (Bos-Brouwers 2009). Green innovation enables the firms to develop and produce products that have favorable impact on the environment (Huang and Li 2017). Green innovation and eco-innovation also refers to businesses' contribution towards sustainable development, while increasing competitive advantage of the firms (OECD 2010; Huang and Li 2017). Based on the evidence of past studies, this study believes that green entrepreneurial orientation (GEO) acts as an independent system that reflects firms' strategic gestures to accelerate green innovation and improve sustainable business performances (environmental, economic, and social). Based on the above arguments, the following hypothesis is proposed:

Hypothesis 1 (H1). Green entrepreneurial orientation has a positive effect on green innovation.

\subsection{The Relationship between Green Innovation and Social, Environmental, and Economic Performance}

The Triple Bottom Line (TBL) model highlighted the importance of the economy, society, and environment as the dimensions of firm performance (Asadi et al. 2020; Elkington 1998). This study has included all three dimensions from the perspective of SMEs as these are critical for sustainable innovation and business performance (Asadi et al. 2020). In line with this, the scholars have pointed out the importance of financial performance, social welfare, and 
environmental quality in the wellbeing of the general public (Tanwir et al. 2020; Shen et al. 2017). However, scholars argue that organizations are more focused on the economic element as compared to social and environmental (Asadi et al. 2020). Some scholars tried to maintain the balance between economic and social on one hand (Haffar and Searcy 2017) and economic and environmental on the other hand (Susanto et al. 2019; Salzmann et al. 2005). For the successful operations of the business, all components have a crucial role in the success of business performance (Fernando et al. 2019).

From the economic perspective, the implementation of green strategies raises the market position of firms and improves financial performance (Battisti and Perry 2011; Green and Inman 2005). The impact of green strategies can be observed at the organizational level as well as financial indices, customers, suppliers, and the government (Asadi et al. 2020; Virglerová et al. 2016). Other scholars have inferred that green innovation directly affects operational performances that lead towards the economic success of the firms (Asadi et al. 2020; Roca and Searcy 2012; Bock and Hasenkamp 2013). Additionally, green innovation practices reduce the costs of energy consumption and reduce discharge wastes that affect organizational costs positively (Zhu and Sarkis 2004). In line with this, Zhu and Sarkis (2004) pointed out the favorable effect of green innovations on the economic performance of the firms due to reduced wastes and costs. Based on the past evidence regarding the positive effects of green innovation on the economic performance of the firms, the following hypothesis is proposed:

Hypothesis 2 (H2). Green innovation has a positive effect on economic performance.

The firms that reduce waste generation and emissions of carbon dioxide, along with the decrease of poisonous substances, are involved in environmental performance (Asadi et al. 2020; Gault 2018; Gavurová et al. 2020). Organizations around the globe are adopting environmental strategies that help to accelerate environmental performances and achieve competitive advantage (Pakurár et al. 2020; Rodríguez-Antón et al. 2012). About this, environmental laws also exert pressure on the manager to comply with environmental performances (B. DiPietro et al. 2013). Environmental performance is an important component of organizational strategy as it encompasses the green innovation and business strategies that create a competitive edge in the market (Dangelico and Pujari 2010). As a result, the organizations that adopted environmental performance as part of organizational strategies have a competitive advantage (Yang et al. 2011). Present literature reveals that improved operational activities and higher productivity lead to better environmental performances of the firms (Asadi et al. 2020; Kozubíková et al. 2017; Montabon et al. 2007). Based on the evidence of previous studies, the following hypothesis is proposed:

Hypothesis 3 (H3). Green innovation has a positive effect on environmental performance.

Apart from addressing environmental issues, green innovations are vital in attracting and retaining staff, maintaining better communications, and increasing the acceptability of the brand. Furthermore, it has several other benefits which include awareness of social responsibility, recruitment, and retaining suitable people (Ključnikov et al. 2020; Mehta and Chugan 2015; Crisan et al. 2015). Indeed, as inferred by Wagner (2013), the performance of the firms that invest in social accountability, pay appropriate attention to satisfied customers through innovations, and appoint suitable staff increases. Past studies depict that the green performance of businesses improves social performance (Dias-Sardinha and Reijnders 2005; Asadi et al. 2020). Based on the evidence of previous work, the following hypothesis is proposed:

Hypothesis 4 (H4). Green innovation has a positive effect on social performance.

Figure 1 show the progressions of the relationship where Green Entrepreneurial Orientation leads to Green Innovation, which in turn gives rise to three variables with 
positive effects. They include Green Social Performance, Green Economic Performance and Green Environmental Performance.

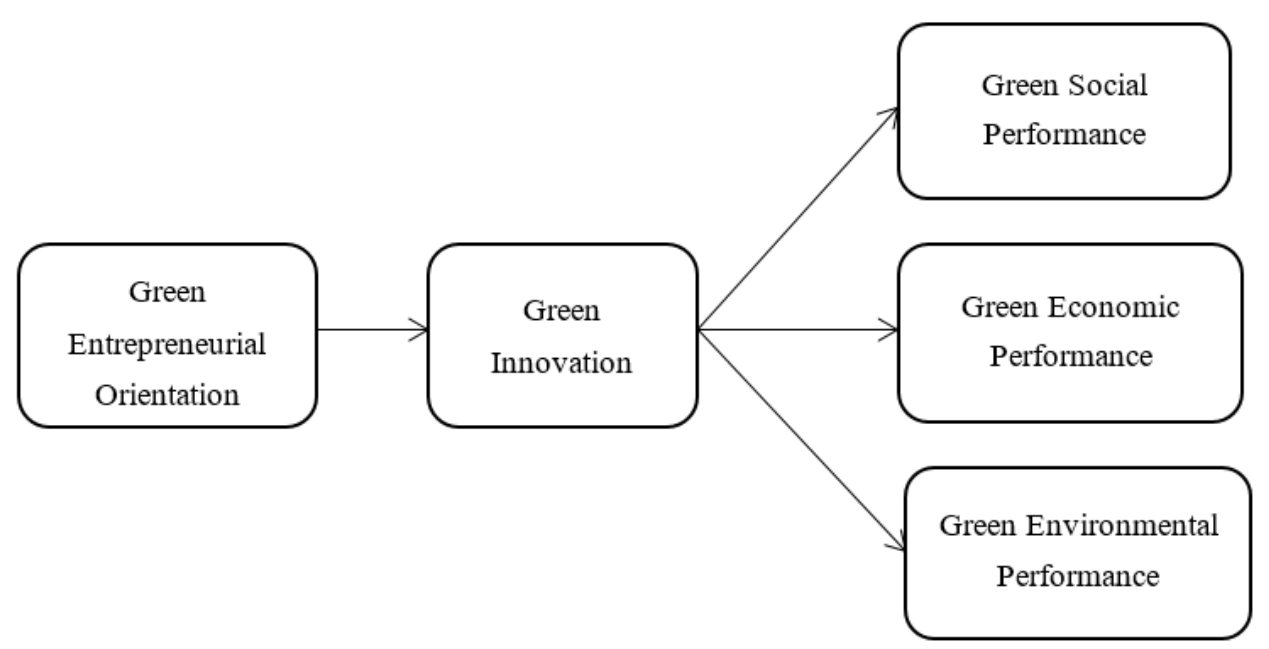

Figure 1. Conceptual Framework.

\section{Research Methodology}

This study collected data from Thai SMEs in the automotive parts industry to test the proposed conceptual framework. The automotive parts industry is one of the key sectors that are important for the economy of Thailand (Na-Nan et al. 2020). The understanding of the role of green entrepreneurial orientation is critical for the growth of the emerging Thai economy. The ministry of industry Thailand defines and classified SMEs in manufacturing sectors as having not more than 200 employees and having fixed assets up to 200 THB million. Following this definition, we have purposively selected samples from the automotive parts industry of Thailand. The automotive parts manufacturing firms were selected from the registered SMEs with the Department of Industrial Works database, Ministry of Industry of Thailand because this study is restricted to the sample of automotive parts industry in Thailand. Through a structured questionnaire survey, the data of the targeted firms were collected. The senior managers top executives located in Thailand were the target respondents of this study. For data collection, we have taken help of five post graduate students. The authors provided the details of the firms along with email id of the managers to students for the collection of data. Initially we decided to distribute questionnaires to more than 700 firms' managers but due to time constraints and some invalid email address, we have decided to distribute to 450 managers. The questionnaire along with a cover letter mentioning the detailed purpose of the study was sent to the managers of the firms. A total of 450 questionnaires were distributed to the top management of firms. In the end, we have received 238 questionnaires but only 226 were valid for the data analysis with an effective response rate of $56.5 \%$. The sample characteristics of the respondents are presented in Table 1 below.

The survey questionnaire, along with a cover letter that ensured confidentiality of the respondents, was distributed to the respondents of the study. The first section of the survey questionnaire consisted of all constructs (see Appendix A), namely, green entrepreneurial orientation (GEO), green innovation (GI), and sustainable business performance (environmental performance (ENP), economic performance (ECP), and social performance (SP). The second section was related to firms' profiles and demographic characteristics of top management. A 5-point Likert scale was used for the measurement. All measurements used a 5-point Likert-type scale. To ensure reliability and validity, we assembled our questionnaire using established survey items to fit our research context. To ensure the content validity of this study, the adapted questionnaire was evaluated by five academic experts. They made minor changes in the format, spelling, and language of the survey questionnaire. Before formal distribution of the questionnaire to the target respondents, a 
pilot study was conducted on 30 mid-level managers and 17 senior managers and 4 top executives of the firms.

Table 1. Profile of the Respondents.

\begin{tabular}{ccc}
\hline Characteristics & Frequency & Percentage \\
\hline Gender & 139 & \\
Male & 87 & 61.5 \\
Female & & 38.5 \\
Age in years & 42 & \\
$25-30$ & 58 & 18.6 \\
$31-35$ & 36 & 25.7 \\
$36-40$ & 60 & 15.9 \\
$41-45$ & 30 & 26.5 \\
$>45$ & & 13.3 \\
Experience in years & 68 & 30.1 \\
$<5$ & 71 & 31.4 \\
$5-10$ & 56 & 24.8 \\
$11-15$ & 31 & 13.7 \\
$>15$ & & \\
Firms age & 59 & 26.1 \\
$<3$ & 88 & 38.9 \\
$3-5$ & 61 & 27.0 \\
$6-8$ & 18 & 8.0 \\
$>8$ & & \\
\hline
\end{tabular}

The questionnaire consists of previously established scales from past studies. Five items for the measurement of green entrepreneurial orientation were adapted from the study by Guo et al. 2020 and Jiang et al. 2018. Four items of green innovation were adapted from the study of Asadi et al. 2020 and Chen 2008. Five items for the measurement of environmental performance were adapted from the study of Asadi et al. 2020, Wang 2019; and Ramanathan 2018. Four items of economic performance were adapted from the study of Li 2014 and Zhu et al. 2008. Finally, four items of social performance were adapted from the study of Asadi et al. (2020); Cheah et al. (2019).

\section{Results}

This study used Partial Least Squares Structural Equation Modelling (PLS-SEM) for the analysis of data. PLS-SEM can easily run regression analysis to test complex relationship among the constructs. Due to PLS-SEM's non-parametric nature, it does not require the assumption of normality and large sample size (Hair et al. 2011). It is a multivariate technique that assesses the measurement and structural model with low error variance. In this study, PLS-SEM software version 3 is used to test the conceptual framework and describe the relationships among the constructs (Hair et al. 2014). PLS-SEM is suitable as it simultaneously validates and describes the relationship among the constructs (Hair et al. 2014). A bootstrapping method using 5000 resampling was used to assess the structural model.

Common method bias (CMB) is a serious threat to the credibility of data. The data collected from a single source will cause CMB. To avoid common method bias, this study made questionnaires anonymous, which allows respondents to be more open and freer in their responses as well as increasing the response rates (Miller and Cardinal 1994). In addition to this, we have used Harman's single factor test (Podsakoff et al. 2003). The results show that a single factor contributes $28.757 \%$ of the variance which is less than $50 \%$ variance. Therefore, this study depicts that common method bias was not a serious problem.

Reliability represents the internal consistency of the data. First, we assessed the internal consistency through Cronbach's alpha and composite reliability (CR) values in Table 2 below. The Cronbach's alpha values $\geq 0.70$ represent internal consistency in the data (Hair et al. 2014). However, composite reliability is the better predictor of internal 
consistency (Hair et al. 2014); therefore, we also measured CR values. The composite reliability (CR) values of all constructs were greater than 0.70 , representing the internal consistency of the data. For the measurement of convergent validity, two validity tests were performed: convergent validity and discriminant validity. Convergent validity refers to the degree of relationship among the constructs. Discriminant validity tests whether constructs are unrelated to each other. According to Hair et al. (2014), convergent validity establishes when the values of average variance are extracted $(\mathrm{AVE}) \geq 0.50$. In this study the values of all constructs' AVE ranges were 0.534 to 0.763 , thus confirming convergent validity, as shown in Table 2 below. Fornell and Larcker's (1981) criterion and Heterotrait-Monotrait (HTMT) methods were used to assess the discriminant validity in Table 3 below. The values of the square root of AVEs are greater than corresponding correlations among the constructs, confirming discriminant validity (Fornell and Larcker 1981; Farrell 2010). Next, the assessments of HTMT values also confirmed discriminant validity as the ratio between two constructs were less than 0.90 (Henseler et al. 2015).

Table 2. Constructs' reliability and convergent validity.

\begin{tabular}{|c|c|c|c|c|c|}
\hline Constructs & Indicator & Loading & CA & CR & AVE \\
\hline \multirow[t]{5}{*}{$\begin{array}{l}\text { Green Entrepreneurial } \\
\text { Orientation }\end{array}$} & GEO1 & 0.824 & 0.909 & 0.932 & 0.732 \\
\hline & GEO2 & 0.891 & & & \\
\hline & GEO3 & 0.820 & & & \\
\hline & GEO4 & 0.840 & & & \\
\hline & GEO5 & 0.899 & & & \\
\hline \multirow[t]{4}{*}{ Green Innovation } & GI1 & 0.831 & 0.825 & 0.884 & 0.658 \\
\hline & GI2 & 0.740 & & & \\
\hline & GI3 & 0.892 & & & \\
\hline & GI4 & 0.772 & & & \\
\hline \multirow{5}{*}{$\begin{array}{l}\text { Environmental } \\
\text { Performance }\end{array}$} & ENP1 & 0.916 & 0.890 & 0.919 & 0.697 \\
\hline & ENP2 & 0.836 & & & \\
\hline & ENP3 & 0.900 & & & \\
\hline & ENP4 & 0.844 & & & \\
\hline & ENP5 & 0.652 & & & \\
\hline \multirow[t]{4}{*}{ Economic Performance } & ECP1 & 0.909 & 0.898 & 0.928 & 0.763 \\
\hline & $\mathrm{ECP} 2$ & 0.865 & & & \\
\hline & ECP3 & 0.905 & & & \\
\hline & $\mathrm{ECP} 4$ & 0.809 & & & \\
\hline \multirow[t]{4}{*}{ Social Performance } & SP1 & 0.820 & 0.733 & 0.818 & 0.534 \\
\hline & SP2 & 0.831 & & & \\
\hline & SP3 & 0.647 & & & \\
\hline & SP4 & 0.597 & & & \\
\hline
\end{tabular}

Note: CA = Cronbach's alpha; CR = Composite reliability; AVE = Average variance extracted.

Table 3. Discriminant Validity.

\begin{tabular}{cccccc}
\hline Latent Variables & $\mathbf{1}$ & $\mathbf{2}$ & $\mathbf{3}$ & $\mathbf{4}$ & $\mathbf{5}$ \\
\hline Economic Performance & $\mathbf{0 . 8 7 3}$ & & & \\
\hline $\begin{array}{c}\text { Environmental } \\
\text { Performance }\end{array}$ & $0.735(0.805)$ & $\mathbf{0 . 8 3 5}$ & & \\
\hline $\begin{array}{c}\text { Green Entrepreneurial } \\
\text { Orientation }\end{array}$ & $0.109(0.149)$ & $0.109(0.125)$ & $\mathbf{0 . 8 5 5}$ & \\
\hline Green Innovation & $0.410(0.456)$ & $0.318(0.348)$ & $0.224(0.249)$ & $\mathbf{0 . 8 1 1}$ \\
\hline Social Performance & $0.349(0.455)$ & $0.260(0.321)$ & $0.325(0.380)$ & $0.167(0.191)$ \\
\hline
\end{tabular}

Note: Bold diagonal values represent the square of average variance extracted (AVE), italic values in the brackets are the Heterotrait-Monotrait (HTMT) values, and the remaining values are the correlations among the constructs. 


\subsection{Assessment of Structural Model}

The proposed hypotheses were tested using the PLS-SEM technique. The values of predictive relevance were used for the model fit. The values of cross-validated redundancy (Q2) represent the predictive relevance of the model. The values of Q2 should be greater than 0 for the model accuracy (Hair et al. 2014; Henseler et al. 2009). The values of Q2 were determined through the blindfolding method. All the endogenous construct values were greater than 0 , representing model accuracy. The values of path coefficient, $\mathrm{p}$-value, and $\mathrm{t}$-statistics were used to accept and reject the hypotheses as shown in Table 4 below. The strength of the relationship between the variables can be examined through path coefficient values. Path coefficient values near +1 indicate a strong relationship and vice versa (Hair et al. 2016). $p$-Values and t-statistics refer to the acceptance and rejection of the proposed hypotheses. In this study, the conceptual model contains four hypotheses. The results of the tested hypotheses have been summarized in Table 4 below. H1 proposed that green entrepreneurial orientation has a positive effect on green innovation, which was accepted ( $\beta=0.224, p<0.002, \mathrm{t}=3.137) ; \mathrm{H} 2$, which proposed that green innovation has positive effect on economic performance, was accepted ( $\beta=0.410, p<0.000, t=5.655)$; and H3, which proposed that green innovation has a positive effect on environmental performance, was rejected $(\beta=0.318, p<0.000, t=4.085)$. Finally, $\mathrm{H} 4$ proposed that green innovation has a positive effect on social performance, which was accepted $(\beta=0.167, p<0.025, t=2.235)$. As evident from the findings, green innovation has a huge impact on the different factors of performances (economic, environmental, and social).

Table 4. Hypotheses Testing Results.

\begin{tabular}{ccccc}
\hline Hypotheses & Path Coefficient & $\boldsymbol{p}$-Values & $\boldsymbol{t}$-Values & Decision \\
\hline GEO $\rightarrow$ GI & 0.224 & 0.002 & 3.137 & Supported \\
GI $\rightarrow$ EP & 0.410 & 0.000 & 5.655 & Supported \\
GI $\rightarrow$ ENP & 0.318 & 0.000 & 4.085 & Supported \\
GI $\rightarrow$ SP & 0.167 & 0.025 & 2.235 & Supported
\end{tabular}

Note: GEO = Green entrepreneurial orientation; GI = Green innovation; SP = Social performance; EP = Environmental performance; ENP = Environmental performance.

\subsection{Out of the Sample Predictive Power}

Following the guidelines of Shmueli et al. (2019), we ran PLSpredict with 10 folds and 10 repetitions to assess the prediction of the PLS model as illustrated in Figure 2. In this study, PLS-SEM errors are asymmetrical; therefore, we based our predictive assessment on mean absolute error (MAE). Table 5 shows that in the PLS-SEM, most of the indicators have lower MAE values than the linear regression model (LM). Therefore, we concluded that the model has medium to high predictive power.

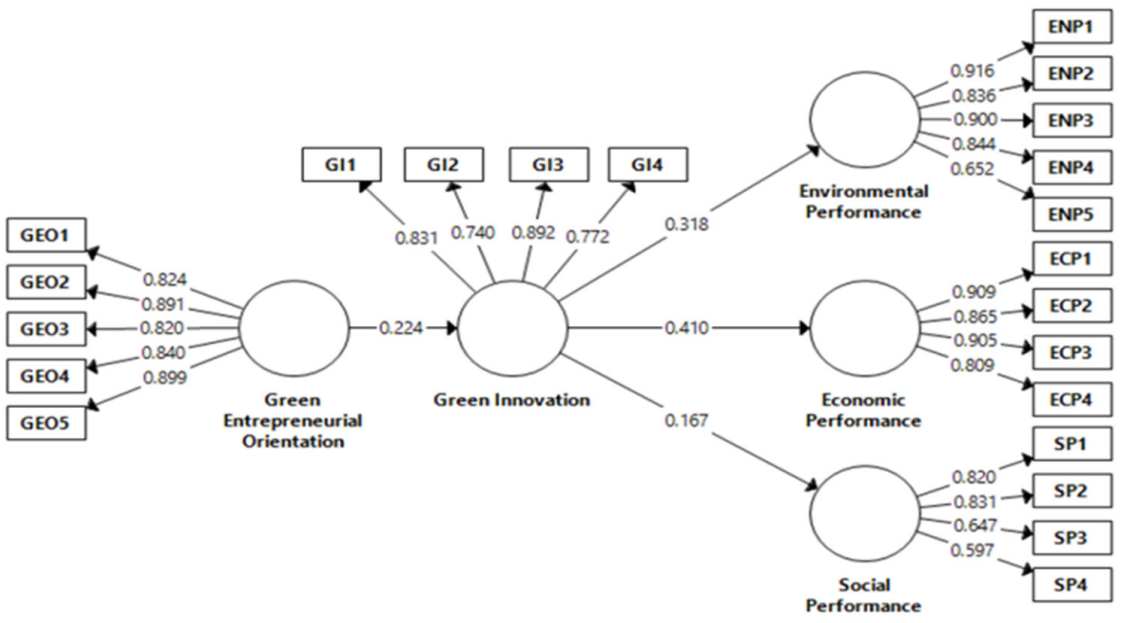

Figure 2. Evaluation of the Structural Model. 
Table 5. PLSpredict assessment of manifest variable.

\begin{tabular}{cccc}
\hline Items & PLS-MAE & LM-MAE & PLS(MAE)-LM(MAE) \\
\hline ECP1 & 0.504 & 0.526 & -0.022 \\
ECP4 & 0.578 & 0.601 & -0.023 \\
ECP3 & 0.551 & 0.57 & -0.019 \\
ECP2 & 0.483 & 0.51 & -0.027 \\
ENP2 & 0.501 & 0.529 & -0.028 \\
ENP4 & 0.52 & 0.543 & -0.023 \\
ENP5 & 0.63 & 0.634 & -0.004 \\
ENP1 & 0.479 & 0.502 & -0.023 \\
ENP3 & 0.461 & 0.493 & -0.032 \\
SP3 & 0.633 & 0.633 & 0 \\
SP4 & 0.75 & 0.754 & -0.004 \\
SP1 & 0.709 & 0.694 & 0.015 \\
SP2 & 0.673 & 0.649 & 0.024 \\
GI1 & 0.539 & 0.553 & -0.014 \\
GI4 & 0.69 & 0.707 & -0.017 \\
GI2 & 0.623 & 0.639 & -0.016 \\
GI3 & 0.616 & 0.63 & -0.014 \\
\hline
\end{tabular}

\subsection{Theoretical Implication}

The present research has multiple theoretical implications that enrich the literature of green entrepreneurship. Although previous studies have contributed to green innovation, studies were limited to the internal and external factors that affect green strategies and performances. The relationship between green entrepreneurial orientation and green innovation is unique, and has not received ample attention from scholars. Green entrepreneurial orientation is an important factor that affects firms' green strategies and leads towards green innovation, and this link will enrich the body of literature. Green innovation is an important aspect of organizational capabilities that drive firm performance, particularly in the automotive industry performance. The inclusion of green innovation into RBV provides a novel theoretical lens to ascertain firms' performance in emerging markets. Second, previous studies have focused on the relationship between entrepreneurial orientation and innovation and did not consider the sustainability aspect (Shan et al. 2016; Miao et al. 2017). This study has extended the literature by incorporating sustainability into the proposed theoretical framework. Third, the study analyzed the mechanism of green entrepreneurial orientation on green innovation that ultimately creates competitive advantage and improves sustainable business performances in the perspective of SMEs, enriching the literature on resources-based view theory. Further, the proposed theoretical model helps the policymakers and entrepreneurs in understanding the factors that affect SME's sustainable performances.

\subsection{Practical Implication}

This study has numerous practical implications for the managers and policymakers that sustained the competitive advantage of SMEs. First, from the perspective of green entrepreneurial orientation, this study found that it has a significant impact on the green innovation of the automotive industry in Thailand. To achieve a high level of green innovations, managers and top executives of the automotive industry need to incorporate green entrepreneurial orientation into SME's business strategies. Top management of SMEs should promote and encourage the development of programs that enhance green entrepreneurial orientation in SMEs and increase firms' participation in green innovations.

Second, the results depict that green innovation has a significant impact on economic performance. Therefore, top executives need to formulate strategies that could reduce the cost of operation through superior operational activities, thereby creating a competitive edge and improving the economic performance of the SMEs. Automotive manufacturing firms should utilize renewable resources of energy, introduce energy-efficient technology to reduce energy consumptions, and handle waste and pollutants that reduce the costs of production. 
Inferring from Asadi et al. (2020), firms that invested in green innovation have become more successful and profitable than traditional firms. Therefore, it is suggested that automotive firms should incorporative green technology and promote green innovative processes and production to sustain the growth of business. Third, the findings depict that green innovation has a significant impact on firms' environmental performance, and it is a crucial aspect of sustainable business development in the automotive industry of Thailand. There, it is suggested to policymakers to strengthen environmental laws and provide subsidies to firms to invest in green technology and create a competitive advantage. Further, it is suggested that managers should be aware of government policies concerning environmental issues and integrate environmental problems into strategic decision-making. In addition to this, results depict that green innovations also improve the social performance of the firms and enhance firms' reputation and position in society. Therefore, firms need to invest in technology that reduces the negative impact on the environment and human health.

\subsection{Discussion and Conclusions}

Inspired by the concept of the triple bottom line, this study has constructed a conceptual model based on resource-based view (RBV) theory and assessed the impact of green entrepreneurial orientation (GEO) on green innovation (GI) which ultimately led to social performance (SP), economic performance (EP), and environmental performance of the firms. The findings of the study contribute to resource-based view theory and suggest valuable insights to entrepreneurs regarding the implementation of green strategies. Present literature depicts that very limited studies have been conducted on the influence of green entrepreneurial orientation on green innovation that creates competitive advantage and improve firms' sustainable performances. As indicated by the previous researchers, green innovation is still in the initial phase (Asadi et al. 2020); therefore, this study will contribute theoretically and provide valuable insights to entrepreneurs of the SME sectors that help them to achieve sustainable business performances.

The results of this study reveal the positive impact of green entrepreneurial orientation on green innovation, which corroborates the work of Guo et al. (2020) and Dangelico (2016). This shows that managers and top executives of the automotive parts industry in Thailand should encourage green innovation. Additionally, the findings reveal that green innovation has a positive impact on the social performance of the firms, which supports the work of Jiang et al. (2018). This indicates that green innovation is an important and integral component of social performance. Further, the results reveal that green innovation has a significant impact on firm economic performance, which is in line with the work of Asadi et al. (2020). The findings of the study also confirm the positive effect of green innovation on the environmental performance, which supports the stance of previous researchers who argued that better environmental practices lead to environmental performances (Montabon et al. 2007). As suggested by the previous researchers that firms' performances not only depend upon economic success, but also social performances and environmental factors (Asadi et al. 2020; Chin et al. 2015; Jiang et al. 2018; Paulraj 2011). Therefore, it is imperative for the firms in the automotive industry to triple bottom line strategies at firms' level to boost firm performance.

\subsection{Recommendations}

Although this study presented a novel framework that addresses SME's sustainable performances based on green entrepreneurial orientation and green innovation, there are several limitations of this study. Future research should investigate additional internal and external factors that could influence green innovation and business performances. Another limitation is related to the population of the study which is the automotive parts industry of Thailand. This indicates that there may be generalization issues as different industries have different behavior. Therefore, it is suggested that future research should attempt to draw conclusions from different emerging economies such as Vietnam, Romania, China, Pakistan, Russia, etc. 
Author Contributions: All authors have contributed substantially to the entire work reported. Conceptualization, C.M., Z.D.-P.; Methodology, N.M., N.K.; Writing-Drafting, B.K. All authors have read and agreed to published version of manuscript.

Funding: The research was funded under the program of the Minister of Science and Higher Education titled "Regional Initiative of Excellence" in 2019-2022, project number 018/RID/2018/19, the amount of funding PLN 10788 423,16.

Informed Consent Statement: Informed consent was obtained from all subjects involved in the study.

Data Availability Statement: Data is not publicly available, though the data may be made available on request from the corresponding author.

Conflicts of Interest: The authors declare no conflict of interest.

\section{Appendix A}

\begin{tabular}{ll}
\hline Constructs & Sources \\
\hline Environmental Performance & Asadi et al. (2020); Wang (2019); \\
ENP1: Our organization has achieved important environment-related certifications. & \\
ENP2: On average, the overall environmental performance of our organization has & \\
improved over the past five years. & \\
ENP3: The resource consumption our organization e.g. water, electricity, and gas has been & \\
decreased during the last 3 years. & \\
ENP4: Our organization has improved on environmental compliance. & \\
ENP5: Our organization is complying with environmental regulations (i.e., carbon dioxide & \\
emissions, waste disposal). &
\end{tabular}

\section{Economic Performance}

Li (2014); Zhu et al. (2008)

EP1: Our organization has decrease of cost for energy consumption.

EP2: Our organization has improved capacity utilization.

EP3: Our organization has decreased the fee for waste treatment.

EP4: Our organization has decreased the penalty costs for environmental accident.

\section{Social Performance}

Asadi et al. (2020); Cheah et al. (2019)

SP1: The customers' satisfaction has increased during the last 3 years.

SP2: The customers' motivation has increased during the last 3 years.

SP3: Our organization serving more beneficiaries (disadvantaged people) or solving

environmental issues.

SP4: Our organization provides more social or environmentally friendly services in the community

\section{Green Innovation}

Asadi et al. (2020); Chen (2008)

GI1: Our organization uses less or non-polluting/toxic materials.

GI2: Our organization improves environmentally friendly packaging for existing and new products.

GI3: Our organization recovers end-of-life products and recycling.

GI4: Our organization uses eco-labeling.

\section{Green entrepreneurial Orientation}

GEO1: Our organization uses less or non-polluting/toxic materials.

GEO2: Our organization has a strong tendency for high-risk green product development projects which have a chance for very high returns.

GEO3: Our firm organization a strong emphasis on green R\&D, technological leadership, and innovation.

GEO4: Our firm organization a tendency to initiate green actions for competitors to respond to.

GEO5: Our organization has a tendency to be a market leader, always first in introducing green products, services, or technologies. 


\section{References}

Arruda, Maria Cecilia. 1999. Isaak, Robert. Green Logic: Ecopreneurship, Theory and Ethics. Teaching Business Ethics 3: 302-4. [CrossRef]

Asadi, Shahla, Seyedeh OmSalameh Pourhashemi, Mehrbakhsh Nilashi, Rusli Abdullah, Sarminah Samad, Elaheh Yadegaridehkordi, Nahla Aljojo, and Nor Shahidayah Razali. 2020. Investigating Influence of Green Innovation on Sustainability Performance: A Case on Malaysian Hotel Industry. Journal of Cleaner Production 258: 120860. [CrossRef]

Battisti, Martina, and Martin Perry. 2011. Walking the talk? Environmental responsibility from the perspective of small-business owners. Corporate Social Responsibility and Environmental Management 18: 172-85. [CrossRef]

Becker, Holger. 2010. Start Me up ... . Lab on a Chip 10: 3197. [CrossRef]

Belás, Jaroslav, Přemysl Bartoš, Jozef Habánik, and Petr Novák. 2014. Significant Attributes of the Business Environment in Small and Meduim-Sized Enterprises. Economics \& Sociology 7: 22-39. [CrossRef]

Belas, Jaroslav, Zdeněk Strnad, Beata Gavurova, and Martin Čepel. 2019. Business Environment Quality Factors Research-SME Management's Platform. Polish Journal of Management Studies 20: 64-77. [CrossRef]

Bock, J., and H. Hasenkamp. 2013. Innovation through Craftmanship. Management \& Marketing Challenges for the Knowledge Society 8: 451-78.

Borghesi, Simone, Giulio Cainelli, and Massimiliano Mazzanti. 2015. Linking emission trading to environmental innovation: Evidence from the Italian manufacturing industry. Research Policy 44: 669-83. [CrossRef]

Bos-Brouwers, Hilke Elke Jacke. 2009. Corporate sustainability and innovation in SMEs: Evidence of themes and activities in practice. Business Strategy and the Environment. [CrossRef]

Chang, Ching-Hsun, and Yu-Shan Chen. 2013. Green organizational identity and green innovation. Management Decision 51: 1056-70. [CrossRef]

Cheah, Jeffrey, Azlan Amran, and Sofri Yahya. 2019. Internal oriented resources and social enterprises' performance: How can social enterprises help themselves before helping others? Journal of Cleaner Production 211: 607-19. [CrossRef]

Chen, Yu-Shan. 2008. The Driver of Green Innovation and Green Image-Green Core Competence. Journal of Business Ethics 81: 531-43. [CrossRef]

Chin, Thoo Ai, Huam Hon Tat, and Zuraidah Sulaiman. 2015. Green Supply Chain Management, Environmental Collaboration and Sustainability Performance. Procedia CIRP 26: 695-699. [CrossRef]

Chiou, Tzu-Yun, Hing Kai Chan, Fiona Lettice, and Sai Ho Chung. 2011. The influence of greening the suppliers and green innovation on environmental performance and competitive advantage in Taiwan. Transportation Research Part E: Logistics and Transportation Review 47: 822-36. [CrossRef]

Chuang, Shan-Ping, and Chang-Lin Yang. 2014. Key success factors when implementing a green-manufacturing system. Production Planning \& Control 25: 923-37. [CrossRef]

Cohen, Boyd, and Monika I. Winn. 2007. Market imperfections, opportunity and sustainable entrepreneurship. Journal of Business Venturing 22: 29-49. [CrossRef]

Crisan, Catalina Mitra, Dan-Cristian Dabija, and Vasile Dinu. 2015. Social Entrepreneurship in Romania: Significance and Models. Montenegrin Journal of Economics 11: 65-77. [CrossRef]

Dangelico, Rosa Maria. 2016. Green Product Innovation: Where we are and Where we are Going. Business Strategy and the Environment 25: 560-76. [CrossRef]

Dangelico, Rosa Maria, and Devashish Pujari. 2010. Mainstreaming Green Product Innovation: Why and How Companies Integrate Environmental Sustainability. Journal of Business Ethics 95: 471-86. [CrossRef]

Das, Maitreyee, and Krishnamachari Rangarajan. 2020. Impact of policy initiatives and collaborative synergy on sustainability and business growth of Indian SMEs. Indian Growth and Development Review 13: 607-27. [CrossRef]

Dias-Sardinha, Idalina, and Lucas Reijnders. 2005. Evaluating environmental and social performance of large Portuguese companies: A balanced scorecard approach. Business Strategy and the Environment 14: 73-91. [CrossRef]

DiPietro, Robin B., Yang Cao, and Charles Partlow. 2013. Green Practices in Upscale Foodservice Operations. International Journal of Contemporary Hospitality Management 25: 779-96. [CrossRef]

Elkington, John. 1998. Partnerships fromcannibals with forks: The triple bottom line of 21st-century business. Environmental Quality Management 8: 37-51. [CrossRef]

Farrell, Andrew M. 2010. Insufficient discriminant validity: A comment on Bove, Pervan, Beatty, and Shiu (2009). Journal of Business Research 63: 324-27. [CrossRef]

Fernando, Yudi, Charbel Jose Chiappetta Jabbour, and Wen-Xin Wah. 2019. Pursuing green growth in technology firms through the connections between environmental innovation and sustainable business performance: Does service capability matter? Resources, Conservation and Recycling 141: 8-20. [CrossRef]

Fornell, Claes, and David F. Larcker. 1981. Evaluating Structural Equation Models with Unobservable Variables and Measurement Error. Journal of Marketing Research 18: 39. [CrossRef]

Fussler, Claude, and Peter James. 1996. Driving Eco-Innovation: A Breakthrough Discipline for Innovation and Sustainability. London: Pitman Publishers.

Galbreath, Jeremiah. 2019. Drivers of Green Innovations: The Impact of Export Intensity, Women Leaders, and Absorptive Capacity. Journal of Business Ethics 158: 47-61. [CrossRef] 
Gault, F. 2018. Defining and measuring innovation in all sectors of the economy. Research Policy 47: 617-22. [CrossRef]

Gavurová, Beata, Martin Mikeska, and Eva Huculova. 2020. Evaluation of Selected Determinants of Public Procurement in the Health Sector. Administratie si Management Public 34: 45-63. [CrossRef]

Green, K. W., and R. A. Inman. 2005. Using a just-in-time selling strategy to strengthen supply chain linkages. International Journal of Production Research 43: 3437-53. [CrossRef]

Guo, Ying, Lifang Wang, and Yanyu Chen. 2020. Green Entrepreneurial Orientation and Green Innovation: The Mediating Effect of Supply Chain Learning. SAGE Open 10: 215824401989879. [CrossRef]

Haffar, Merriam, and Cory Searcy. 2017. Classification of Trade-offs Encountered in the Practice of Corporate Sustainability. Journal of Business Ethics 140: 495-522. [CrossRef]

Hair, Joe F., Marko Sarstedt, Christian M. Ringle, and Jeannette A. Mena. 2011. An assessment of the use of partial least squares structural equation modeling in marketing research. Journal of the Academy of Marketing Science 40: 414-33. [CrossRef]

Hair, Joe F., Jr., Marko Sarstedt, Lucas Hopkins, and Volker G. Kuppelwieser. 2014. Partial least squares structural equation modeling (PLS-SEM). European Business Review 26: 106-21. [CrossRef]

Hair, Joseph F., Jr., G. Tomas M. Hult, Christian Ringle, and Marko Sarstedt. 2016. A Primer on Partial Least Squares Structural Equation Modeling (PLS-SEM), 2nd ed. Thousan Oaks: SAGE Publications, Inc.

Henseler, Jörg, Christian M. Ringle, and Marko Sarstedt. 2015. A new criterion for assessing discriminant validity in variance-based structural equation modeling. Journal of the Academy of Marketing Science 43: 115-35. [CrossRef]

Henseler, Jörg, Christian M. Ringle, and Rudolf R. Sinkovics. 2009. The use of partial least squares path modeling in international marketing. Advances in International Marketing, 277-319. [CrossRef]

Huang, Jing-Wen, and Yong-Hui Li. 2017. Green innovation and performance: The view of organizational capability and social reciprocity. Journal of Business Ethics 145: 309-24. [CrossRef]

Jiang, Wenbo, Huaqi Chai, Jing Shao, and Taiwen Feng. 2018. Green entrepreneurial orientation for enhancing firm performance: A dynamic capability perspective. Journal of Cleaner Production 198: 1311-23. [CrossRef]

Ključnikov, Aleksandr, Mehmet Civelek, Vladimír Krajčík, and Ivana Ondrejmišková. 2020. Innovative Regional Development of the Structurally Disadvantaged Industrial Region by means of the Local Currency. Acta Montanistica Slovaca 25: 224-35. [CrossRef]

Kozubíková, Ludmila, Gabriela Sopková, Vladimír Krajčík, and Ladislav Tyll. 2017. Differences in innovativeness, proactiveness and competitive aggressiveness in relation to entrepreneurial motives. Journal of International Studies 10: 207-18. [CrossRef] [PubMed]

Leonidou, Leonidas C., Paul Christodoulides, Lida P. Kyrgidou, and Daydanda Palihawadana. 2017. Internal Drivers and Performance Consequences of Small Firm Green Business Strategy: The Moderating Role of External Forces. Journal of Business Ethics 140: 585-606. [CrossRef]

Li, Yina. 2014. Environmental innovation practices and performance: Moderating effect of resource commitment. Journal of Cleaner Production 66: 450-58. [CrossRef]

Liu, Lei, Martin de Jong, and Ying Huang. 2016. Assessing the administrative practice of environmental protection performance evaluation in China: The case of Shenzhen. Journal of Cleaner Production 134: 51-60. [CrossRef]

Lumpkin, G. Tom, and Gregory G. Dess. 1996. Clarifying the Entrepreneurial Orientation Construct and Linking It to Performance. Academy of Management Review 21: 135-72. [CrossRef]

Luo, Xueming, Lianxi Zhou, and Sandra S. Liu. 2005. Entrepreneurial firms in the context of China's transition economy: An integrative framework and empirical examination. Journal of Business Research 58: 277-84. [CrossRef]

Mehta, Kathak, and Pawan K. Chugan. 2015. Green HRM in Pursuit of Environmentally Sustainable Business. Universal Journal of Industrial and Business Management 3: 74-81. [CrossRef]

Miao, Chao, Joseph E. Coombs, Shanshan Qian, and David G. Sirmon. 2017. The mediating role of entrepreneurial orientation: A meta-analysis of resource orchestration and cultural contingencies. Journal of Business Research 77: 68-80. [CrossRef]

Miller, C. Chet, and Laura B. Cardinal. 1994. Strategic Planning and Firm Performance: A Synthesis of More Than Two Decades of Research. Academy of Management Journal 37: 1649-65. [CrossRef]

Montabon, Frank, Robert Sroufe, and Ram Narasimhan. 2007. An examination of corporate reporting, environmental management practices and firm performance. Journal of Operations Management 25: 998-1014. [CrossRef]

Na-Nan, Khahan, Peerapong Pukkeeree, and Kanokporn Chaiprasit. 2020. Employee engagement in small and medium-sized enterprises in Thailand: The construction and validation of a scale to measure employees. International Journal of Quality $\mathcal{E}$ Reliability Management 37: 1325-43. [CrossRef]

Organisation for Economic Co-Operation and Development (OECD). 2010. Education at a Glance 2010: OECD Indicators. Paris: OECD, Available online: http:/ / hdl.voced.edu.au/10707/ 49896 (accessed on 15 March 2021).

Pacheco, Desirée F., Thomas J. Dean, and David S. Payne. 2010. Escaping the green prison: Entrepreneurship and the creation of opportunities for sustainable development. Journal of Business Venturing 25: 464-80. [CrossRef]

Pakurár, Miklós, Muhammad Asif Khan, Attila Benedek, and Judit Oláh. 2020. The impact of green practices, cooperation and innovation on the performance of supply chains using statistical method of meta-analysis. Journal of International Studies 13: 111-28. [CrossRef]

Paulraj, Antony. 2011. Understanding the Relationships between Internal Resources and Capabilities, Sustainable Supply Management and Organizational Sustainability. Journal of Supply Chain Management 47: 19-37. [CrossRef] 
Podsakoff, Philip M., Scott B. MacKenzie, Jeong-Yeon Lee, and Nathan P. Podsakoff. 2003. Common method biases in behavioral research: A critical review of the literature and recommended remedies. Journal of Applied Psychology 88: 879-903. [CrossRef]

Ramanathan, Ramakrishnan. 2018. Understanding Complexity: The Curvilinear Relationship between Environmental Performance and Firm Performance. Journal of Business Ethics 149: 383-93. [CrossRef]

Rastogi, Vasundhara. 2018. Thailand's Automotive Industry: Opportunities and Incentives. ASEAN Business News, May 10.

Roca, Laurence Clément, and Cory Searcy. 2012. An analysis of indicators disclosed in corporate sustainability reports. Journal of Cleaner Production 20: 103-18. [CrossRef]

Rodríguez-Antón, José Miguel, María del Mar Alonso-Almeida, María Soledad Celemín, and Luis Rubio. 2012. Use of different sustainability management systems in the hospitality industry. The case of Spanish hotels. Journal of Cleaner Production 22: 76-84. [CrossRef]

Rosenbusch, Nina, Jan Brinckmann, and Andreas Bausch. 2011. Is innovation always beneficial? A meta-analysis of the relationship between innovation and performance in SMEs. Journal of Business Venturing 26: 441-57. [CrossRef]

Salzmann, Oliver, Aileen Ionescu-Somers, and Ulrich Steger. 2005. The Business Case for Corporate Sustainability: Literature review and research options. European Management Journal 23: 27-36. [CrossRef]

Schaefer, Katrin, Patricia Doyle Corner, and Kate Kearins. 2015. Social, Environmental and Sustainable Entrepreneurship Research. Organization E Environment 28: 394-413. [CrossRef]

Shan, Peng, Michael Song, and Xiaofeng Ju. 2016. Entrepreneurial orientation and performance: Is innovation speed a missing link? Journal of Business Research 69: 683-90. [CrossRef]

Shen, Liyin, Zhenyu Zhang, Xiaoling Zhang, Hang Yan, and Bei He. 2017. Measuring incoordination-adjusted sustainability performance during the urbanization process: Spatial-dimensional perspectives. Journal of Cleaner Production 143: 731-43. [CrossRef]

Shmueli, Galit, Marko Sarstedt, Joseph F. Hair, Jun-Hwa Cheah, Hiram Ting, Santha Vaithilingam, and Christian M. Ringle. 2019. Predictive model assessment in PLS-SEM: Guidelines for using PLSpredict. European Journal of Marketing 53: 2322-47. [CrossRef]

Sirmon, David G., Michael A. Hitt, R. Duane Ireland, and Brett Anitra Gilbert. 2010. Resource Orchestration to Create Competitive Advantage. Journal of Management 37: 1390-412. [CrossRef]

Suraraksa, Juthathip, and Kwang Sup Shin. 2019. Comparative analysis of factors for supplier selection and monitoring: The case of the automotive industry in Thailand. Sustainability 11: 981. [CrossRef]

Susanto, Perengki, Nor Liza Abdullah, and Yunia Wardi. 2019. Entrepreneurial Orientation: Prioritising and Mapping in the Context of Small and Medium Sized Enterprises. Polish Journal of Management Studies 20: 429-46. [CrossRef]

Tamayo-Orbegozo, Unai, María-Azucena Vicente-Molina, and Oskar Villarreal-Larrinaga. 2017. Eco-innovation strategic model. A multiple-case study from a highly eco-innovative European region. Journal of Cleaner Production 142: 1347-67. [CrossRef]

Tanwir, M. S. Mahrinasari, and Satria Bangsawan. 2020. The Impact of Entrepreneurial and Environmental Factors on Entrepreneurial Intention of Banking Sector of Indonesia. Polish Journal of Management Studies 21: 412-24. [CrossRef]

Teece, David J. 2016. Dynamic capabilities and entrepreneurial management in large organizations: Toward a theory of the (entrepreneurial) firm. European Economic Review 86: 202-16. [CrossRef]

Varanavicius, Vytis, and Aida Navikaite. 2015. Competitive Advantage Attainment via Synergy in Green Offices. Journal of International Studies 8. [CrossRef]

Virglerová, Zuzana, Ludmila Kozubíková, and Sergej Vojtovič. 2016. Influence of selected factors on financial risk management in SMEs in the Czech Republic. Montenegrin Journal of Economics 12: 21-36. [CrossRef]

Wagner, Marcus. 2013. 'Green' Human Resource Benefits: Do they Matter as Determinants of Environmental Management System Implementation? Journal of Business Ethics 114: 443-56. [CrossRef]

Wang, Chao-Hung. 2019. How organizational green culture influences green performance and competitive advantage. Journal of Manufacturing Technology Management 30: 666-83. [CrossRef]

Weng, Hua-Hung Robin, Ja-Shen Chen, and Pei-Ching Chen. 2015. Effects of Green Innovation on Environmental and Corporate Performance: A Stakeholder Perspective. Sustainability 7: 4997-5026. [CrossRef]

Wernerfelt, Birger. 1984. A resource-based view of the firm. Strategic Management Journal 5: 171-80. [CrossRef]

Woldesenbet, Kassa, Monder Ram, and Trevor Jones. 2012. Supplying large firms: The role of entrepreneurial and dynamic capabilities in small businesses. International Small Business Journal: Researching Entrepreneurship 30: 493-512. [CrossRef]

Xie, Xuemei, Jiage Huo, Guoyou Qi, and Kevin Xiaoguo Zhu. 2016. Green Process Innovation and Financial Performance in Emerging Economies: Moderating Effects of Absorptive Capacity and Green Subsidies. IEEE Transactions on Engineering Management 63: 101-12. [CrossRef]

Xie, Xuemei, Jiage Huo, and Hailiang Zou. 2019. Green process innovation, green product innovation, and corporate financial performance: A content analysis method. Journal of Business Research 101: 697-706. [CrossRef]

Xie, Yang, Hancheng Dai, Huijuan Dong, Tatsuya Hanaoka, and Toshihiko Masui. 2016. Economic Impacts from PM2.5 PollutionRelated Health Effects in China: A Provincial-Level Analysis. Environmental Science E Technology 50: 4836-43. [CrossRef]

Yang, Ma Ga Mark, Paul Hong, and Sachin B. Modi. 2011. Impact of lean manufacturing and environmental management on business performance: An empirical study of manufacturing firms. International Journal of Production Economics 129: 251-61. [CrossRef] 
Zhang, Xiao, Xufei Ma, Yue Wang, Xin Li, and Dong Huo. 2016. What drives the internationalization of Chinese SMEs? The joint effects of international entrepreneurship characteristics, network ties, and firm ownership. International Business Review 25: 522-34. [CrossRef]

Zhao, Yongbin, Yuan Li, Soo Hoon Lee, and Long Bo Chen. 2009. Entrepreneurial Orientation, Organizational Learning, and Performance: Evidence From China. Entrepreneurship Theory and Practice 35: 293-317. [CrossRef]

Zhu, Qinghua, and Joseph Sarkis. 2004. Relationships between operational practices and performance among early adopters of green supply chain management practices in Chinese manufacturing enterprises. Journal of Operations Management 22: 265-89. [CrossRef]

Zhu, Qinghua, Joseph Sarkis, James Cordeiro, and Kee-Hung Lai. 2008. Firm-Level Correlates of Emergent Green Supply Chain Management Practices in the Chinese Context. Omega 36: 577-91. [CrossRef] 